\title{
Prospect of gas industry and the role of liquefied natural gas (LNG) in Vietnam during 2011-2035
}

- Dang Dinh Thang

- Huynh Quyen

- Ta Dang Khoa

Ho Chi Minh city University of Technology, VNU-HCM

(Manuscript Received on July, 2016, Manuscript Revised on September, 2016)

\begin{abstract}
The paper presents the detailed data of gas terminal installation for import is considered as demand for power, fertilizer and other industries in Vietnam during 2011-2015, as well as forecasted data for 2016-2025 and 20262035 phases. The results demonstrate that the domestic gas industry cannot meet the market requirement, the inadequacy is estimated of $30 \%$. Liquefied natural gas (LNG) receiving a feasible solution to the problem. However, the major barrier is that the gas pipeline system is discrete in the whole country, the configuration of $L N G$ receiving terminal must be therefore selected and designed reasonably. By analysis, Vietnamese LNG market is a high potential in 2016-2035 phase.
\end{abstract}

Keywords: Liquefied Natural Gas (LNG), gas industry, LNG market

\section{INTRODUCTION}

The electric energy in Vietnam was previously from hydroelectric and coal. These affect to environment remarkably because of carbon dioxide emission. The energy demand in Vietnam has been increasing dramatically due to industrial development. Under the pressure of accelerating energy demand and environmental preservation, the electric power by hydroelectric and coal is gradually replaced by natural gas turbine in Vietnam since 1995. The gas industry plays therefore a very important role in the
Vietnamese economy as well as the national energy security.

\section{THE VIETNAMESE GAS INDUSTRY DURING THE 2011-2015 PHASE}

In the 2011-2015 phase, the gas industry satisfied the $90.8 \%$ of total demand which comprised $83 \%$ of power production, $11 \%$ of fertilizer production and $6 \%$ of others including compressed natural gas $(\mathrm{CNG})$ for transportation [1]. 


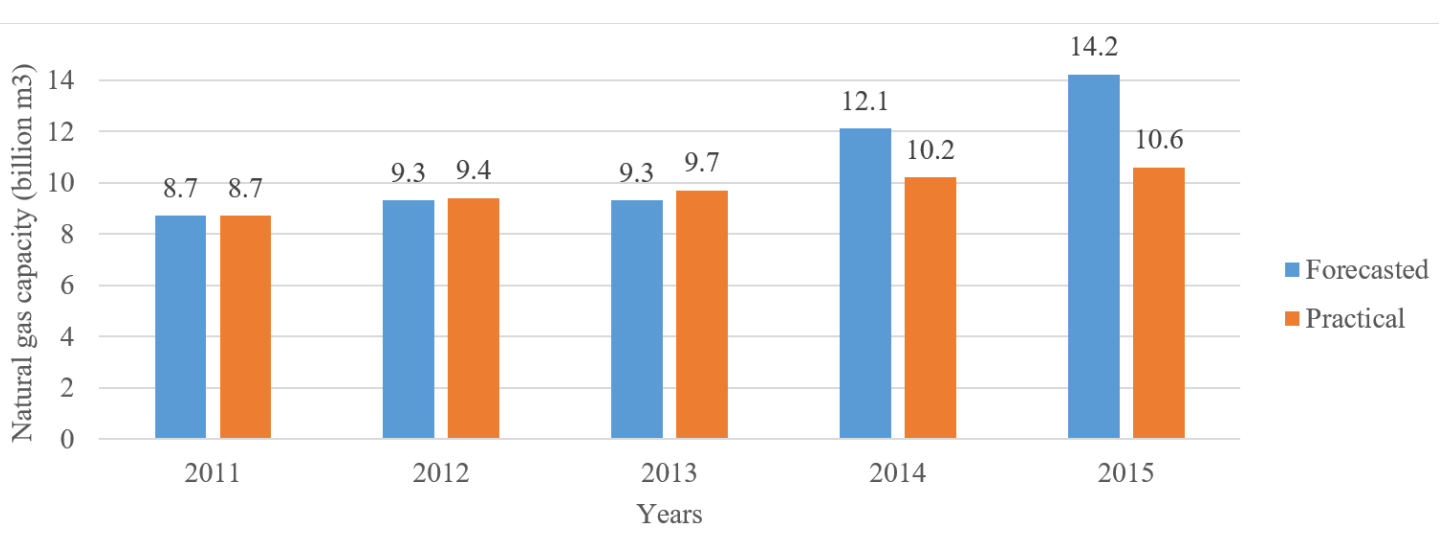

Figure 1. The comparison of forecasted and practical natural gas capacity during 2011-2015 phase [1]

The data is detailed in Figure 1.

In order to reach $90.8 \%$ of total demand, the gas industry received the 4.65 billion USD of investment by government. The practical natural gas gathering increased very slowly in the 2011-2015 phase, because the probe drilling and reserve estimation were not reliable. These caused some wells of low reserve were not able to be commercially exploited. The gas market is almost for power production, but petrochemical industry is just on research. The LNG market has not developed yet since there were not many LNG consumers. Another reason is that the gas pipeline system is discrete in the country as in Figure 2 [2], the gathered natural gas was not then able to balance between the regions.

The detail for regions is as follows:

- For The North region, the wells of low reserve were unavailable for expansion such as Hong Long, Hac Long, Bach Long, Dia Long... Furthermore, the Thai Binh well has only reached 0.02 billion $\mathrm{m} 3$ which was lower than that one of forecast $[1,2]$.

- For The Central region, the reserve of Bao Vang well was too low to develop the power plant, this caused decreasing of natural gas recovery in the region.

- For The Southeast region, the reserve of Thien Ung well reduced to 7.3 billion $\mathrm{m} 3$ compared with that one of forecast. Besides, the $43.3 \%$ of capacity of Hai Thach - Moc Tinh well was cut down due to pipeline switching from Nam Con Son 1 to Nam Con Son $2[1,2]$.

- For The Southwest region, the Block B $48 / 95$ and 52/97 would be exploited of 2.0 billion $\mathrm{m} 3$ per year and increasing to 4.0 billion m3 per year (in 2015) as forecast, however the project has not been reality yet due to the bargain on contract $[1,2]$.

\section{THE VIETNAMESE GAS INDUSTRY DURING THE 2016-2025 PHASE}

The forecast of supply, demand and the supply-demand balance of natural gas for the different regions are shown detailed in Table 1.

Trang 32 


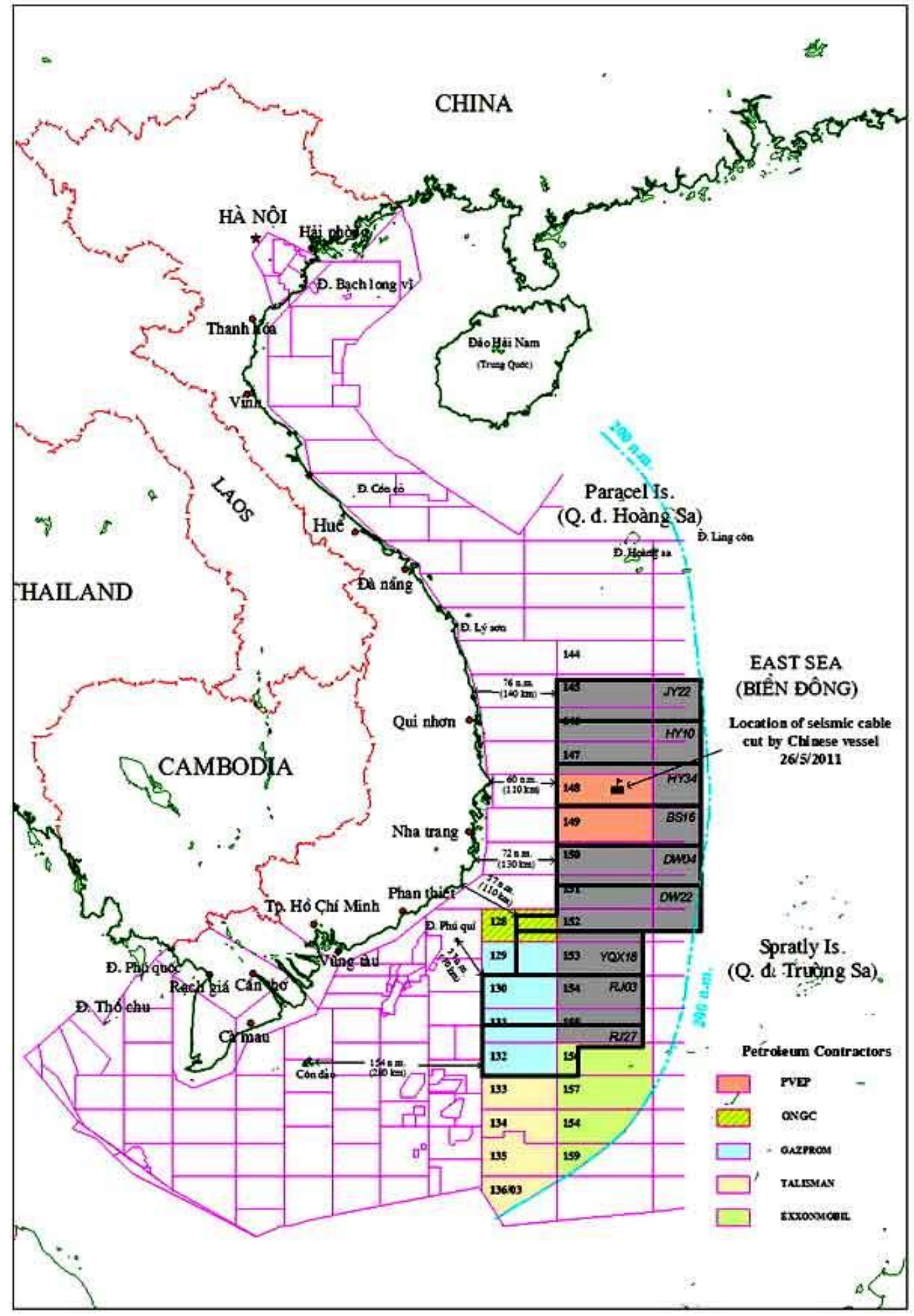

Figure 2. Map of Vietnamese natural gas resource and currently gas pipeline system [2] 
Table 1. The supply, demand and supply-demand balance of natural gas during 2016-2035 in billion $\mathrm{m} 3[1]$

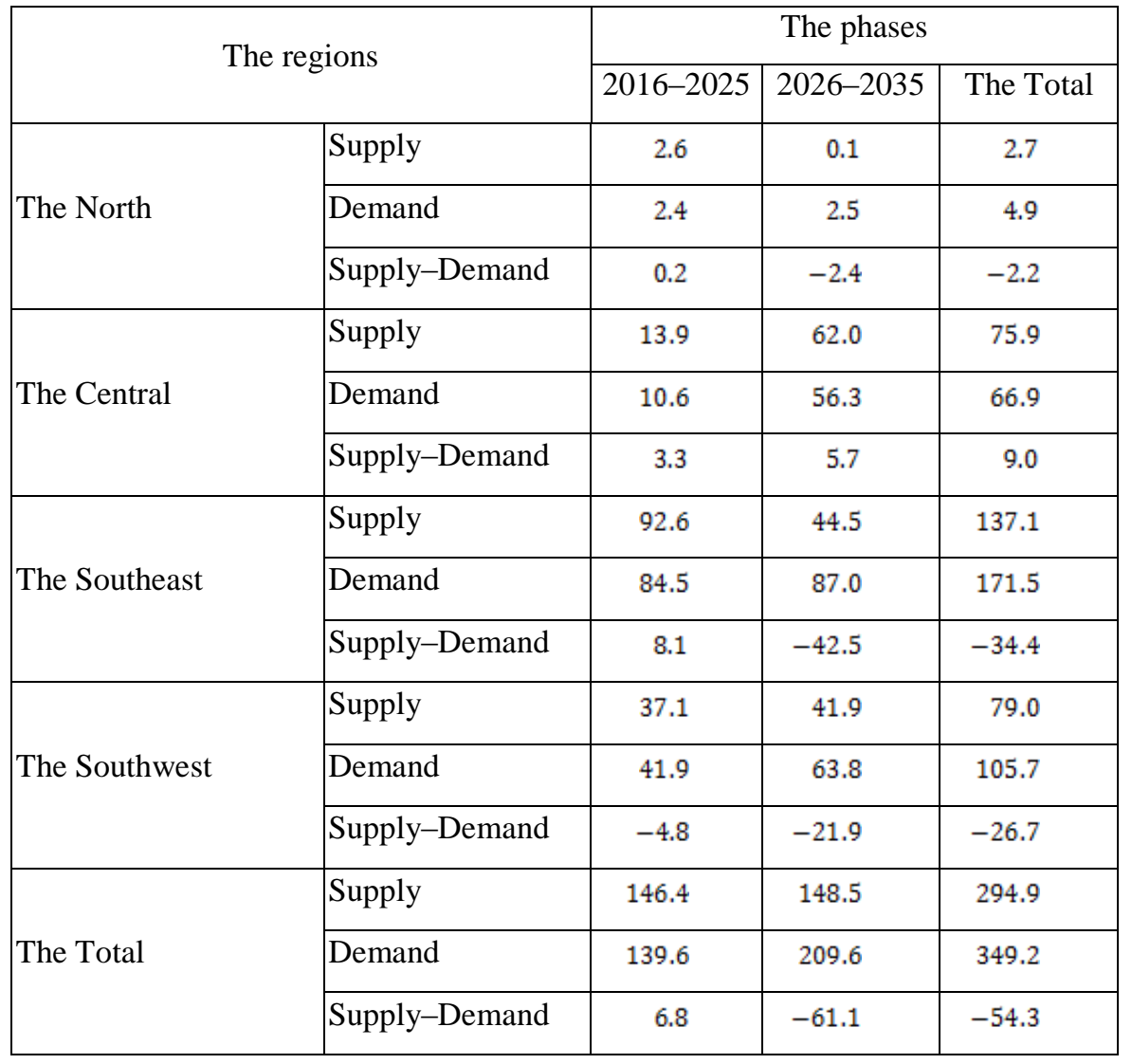

In the 2016-2025 phase, almost of natural gas supply is in The Southeast region, $63 \%$ of the total. The most demand natural gas is $60 \%$ of The Southeast region too. However, the resource in this region is decreased since 2022, while almost of resource will come from The Central and The Southwest regions due to the wells of $\mathrm{Ca}$ Voi Xanh and Block B. The composition of consumers will be hopefully changed a little bit such as $77 \%$ of power production, $16 \%$ of fertilizer production and $7 \%$ of others including compressed natural gas (CNG) for transportation.
The supply-demand balance of natural gas is positive for The North, The Central and The Southeast regions, but negative for The Southwest region. In the total, the supplydemand balance is only +6.8 billion $\mathrm{m}^{3}$ as $4.9 \%$ of demand that is really not safe for new consumers development. Additionally, the current pipeline systems cannot meet the gathered requirement such as Ham Rong - Thai Binh, Bach Ho, Nam Con Son 1, Nam Con Son 2, PM3 - Ca Mau. As consequently, the more gas pipeline system projects need to be installed to satisfy the requirement of consumers. 
The natural gas supply is forecasted in the 2016-2025 phase as in Figure 3.

The total of 146.4 billion $\mathrm{m}^{3}$ forecasted natural gas is too high compared to capability of current pipeline systems during this phase. By the current pipeline system (non-investment), the practical natural gas is only gathered around 55.1 billion $\mathrm{m}^{3}$ as $39 \%$ of demand. The required capital is estimated 8.27 billion USD for installation of gas pipeline systems and LNG receiving terminals. If being invested by government, the gas industry would meet the demand. The disadvantages are low reserve of wells and almost of wells are in deep offshore and separately regions. The cost of exploitation is therefore very expensive. Moreover, some of planning projects are stopped or changed because of low reserve of wells.

\section{THE VIETNAMESE GAS INDUSTRY DURING THE 2026-2035 PHASE}

The data in Table 1 shows that the domestic natural gas resources cannot meet the market demand in the 2026-2035 phase. The supply-demand balance of natural gas is negative for The North, The Southeast and The Southwest regions, but positive for The Central region. The domestic gas would only reach $70 \%$ if all of planning projects are run and completed, the inadequacy of $30 \%$ is hence inevitable. Nevertheless, the inadequacy can be increased because all of projects are difficult to complete in planning. The composition of consumers is hopefully $77 \%$ of power production, $18 \%$ of fertilizer production and $5 \%$ of others including compressed natural gas $(\mathrm{CNG})$ for transportation.

The total natural gas supply during 20162035 is forecasted around 294.9 billion $\mathrm{m}^{3}$ with maximum capacity of 20 billion $\mathrm{m}^{3}$ per year in 2024-2025 because of starting up of new resources such as $\mathrm{Su} \mathrm{Tu}$ Trang, Sao Vang, $\mathrm{Ca}$ Voi Xanh and Block B.

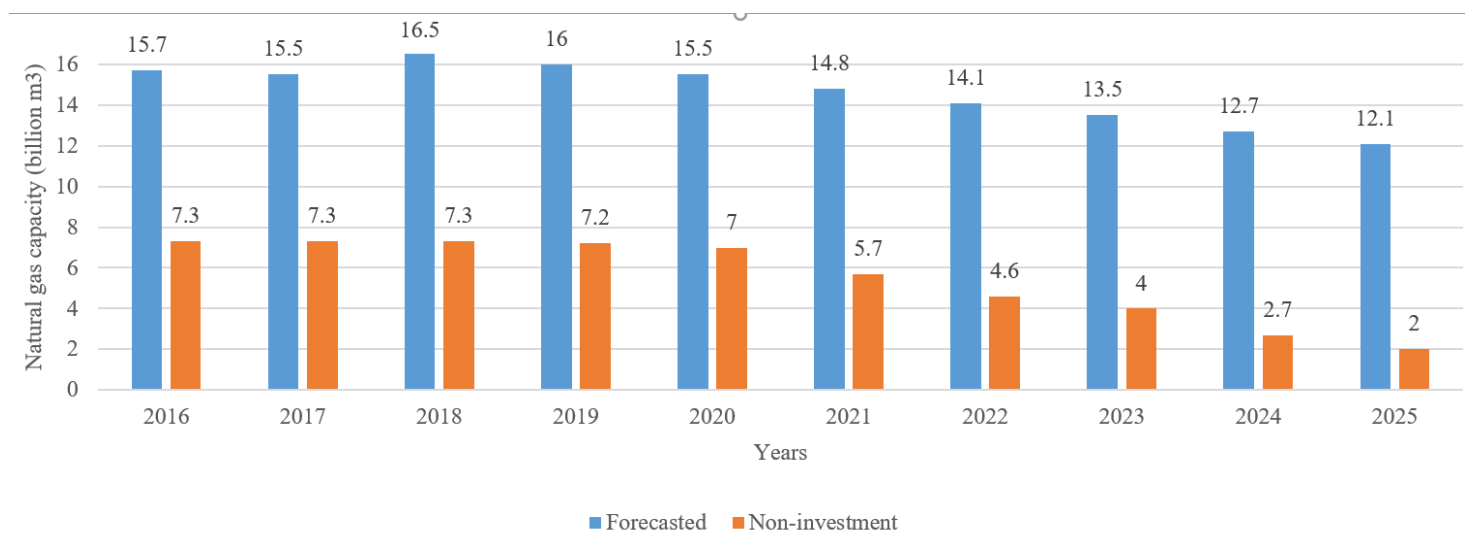

Figure 3. The comparison of forecasted and practical natural gas capacity during 2016-2025 phase [1,2] 


\section{PROBLEMS DEFINITION}

The problems can be specified:

- In the 2016-2025 phase, the gas industry can meet the demand if all the project will be completed in planning with total investment of 8.27 billion USD for pipeline systems and LNG receiving terminals installation. This is also the challenge of Vietnamese gas industry under low price market as current circumstance. In the 2026-2035 phase, the domestic gas resource cannot meet the demand, $30 \%$ of the inadequacy has to compensate by other resource, because the national energy security and preservation of fossil fuel are the missions of oil and gas industry.

- The natural gas basins and consumers are stretched from The North to The South, and the composition of consumers is varied by regions. The gas pipeline system is discrete into three segments including Ham Rong - Thai Binh in The North, Bach Ho - Nam Con Son in The Southeast and PM3 - Ca Mau in The Southwest, it is very difficult for gas distribution and supply-demand balance.

- For The North region, there is only Thai Binh well with high reserve and extended until 10 years forward, it is still hence not enough for gas processing and power plant installation. The Hai Phong 3 power plant $(4 \times 600 M W)$ cannot start up during 20252027 as planned.

- For The Central region, the practical natural gas from Ca Voi Xanh well is over 3 times higher than the forecast. Therefore, the natural gas for 4 power plants $(3000 M W$ in total) in The Central region is contented. Moreover, the natural gas supply will be supplemented by Bao Vang well. As consequently, the petrochemical industry should be considered for development in this region.

- For The Southeast region, the decreasing of reserve at Thien Ung well and the uncompleted Nam Con Son 2 pipeline made the total gathered natural gas decreasing. On the other hand, the Nam Con Son 2 pipeline has not focused on the large reserve of wells such as $\mathrm{Su}$ Tu Trang, Sao Vang, Ca Rong Do, Ca Kiem Xanh, Ca Kiem Nau, Cobia... the reason is that the estimation of gas reserves was not exactly and reliably. These made the power plants are not yet installed as planned, for example Son My $(6 \times 750 M W)$, Nhon Trach 3 and Nhon Trach 4.

- For The Southwest region, the contribution of Kien Giang power plant increased the natural gas demand in the region. The decreasing of PM3CAA resource since 2025 that affects to the natural gas supply. In order to maintain the fuel gas for power plants, the estimation of gas reserves is implemented at new resources of U Minh, Nam Du, Hoa Mai, Khanh My and Dam Doi.

\section{SOLUTIONS SUGGESTION}

In recent situation, LNG import is considered as feasible solution to complement the inadequacy of natural gas in the country. The other reason for this choice is the environment problem $[3,4]$. The natural gas is the most environmental friendly fossil fuels because the mainly composition is methane. 
Accompany to the LNG import, the LNG receiving terminals and regasification process projects have to be run and completed since 2019 in The Southeast region, in The Southwest region since 2022 and in The North region since 2025.

The circumstance in The Central region is better, therefore, there will be two options: installation of small scale LNG production plant for petrochemical industry or connection the gas pipeline system from this region to others.

\section{THE ROLE OF LNG IMPORTATION IN VIETNAMESE GAS INDUSTRY}

The national energy security and sustainable development play the important role in Vietnamese society. As forecasted, LNG has to be imported since 2019 to complement the insufficient natural gas supply. The inadequacy higher to $30 \%$ of demand in the 2026-2035 phase. The requirement of LNG import is forecasted as in Figure 4 [1].
The LNG has to be imported in The Southeast region earliest in 2019, and accelerates the capacity from 2024 . The Thi Vai LNG Import Harbor Depot project with a capacity of 1 million tons per year is being started and expected to come into operation by 2017, while the 3 million tons per year of Son My LNG Import Harbor Depot is predicted to start up during 2019-2020. Almost of LNG import is supplied to the new power plants such as Son My, Nhon Trach $3 \& 4$ and Hiep Phuoc enlargement [1].

The natural gas supply for The Southwest region starts insufficient since 2022, and a new LNG receiving terminal with a capacity of 3 million tons per year is planned to set up at Hon Khoai for supply to power plants in Kien Giang and O Mon [1].

For The North region, the LNG resource which will be imported through the Cat Hai LNG receiving terminal with 1 million tons per year of capacity, supply to the Hai Phong 3 power plant (4 x 600MW) hopefully operating between 2025-2027 [1].

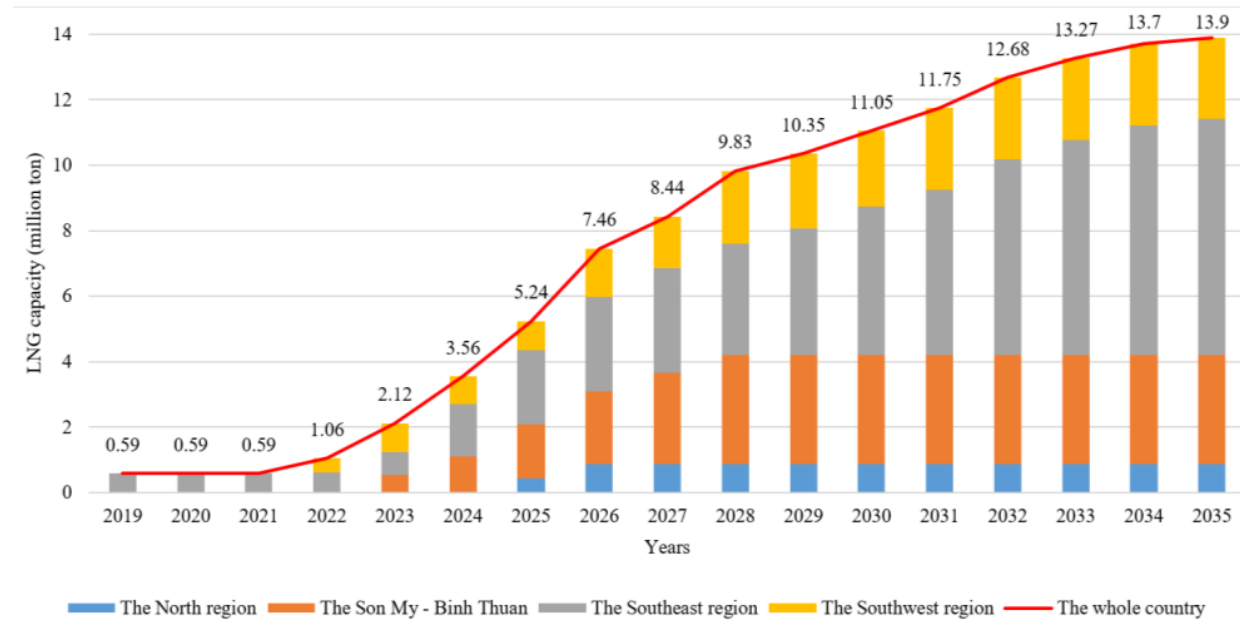

Figure 4. The LNG import capacity during 2019-2035 in million tons [1] 


\section{SELECTION FOR LNG HARBOR DEPOT TECHNOLOGY IN VIETNAM}

There are many modern technology of LNG storage and regasification in the world currently. The technology is applied by the professional group such as Air Products and Chemicals Inc., Linde Group, Costain Energy \& Process... However, it is necessary to select a suitable technology of LNG storage and regasification under Vietnamese conditions presently. The constraints are the small scale and low capital cost of LNG Harbor Depot. The simplified process flow of a LNG Harbor Depot is shown as in Figure 5 [5].

The LNG is pumped to the storage tank from floating production storage and offloading (FPSO) directly. There is always amount of LNG vaporized under storage process which is called boil of gas (BOG). The BOG is normally compressed to liquid and turned back to the storage tank. The LNG is re-gasified before transported to the end consumer by gas pipeline system. The capital cost is almost contributed by the storage tank, compression and regasification processes. Therefore, the LNG storage tank should be designed at an appropriate BOG rate of $0.05 \%$ in mass fraction. This lowers the compression duty, as well as the capital and operation cost of compression process. For regasification process, the open rack vaporizer should be selected because Vietnam is in seaside and tropical region, sea water is as an infinite heat source for LNG vaporization.

Nevertheless, the above solutions are just the first selection for the first phase of the project due to low capital cost. The open rack vaporizers lose a lots of energy saving opportunities. The lost energy in the compression and regasification processes can be saved for power generation, air separation and cold storage [6-9] ... The modern technology and energy saving solutions will be hence applied in the second phase of the project. There will be many opportunities for research, investment and development in Vietnamese LNG market.

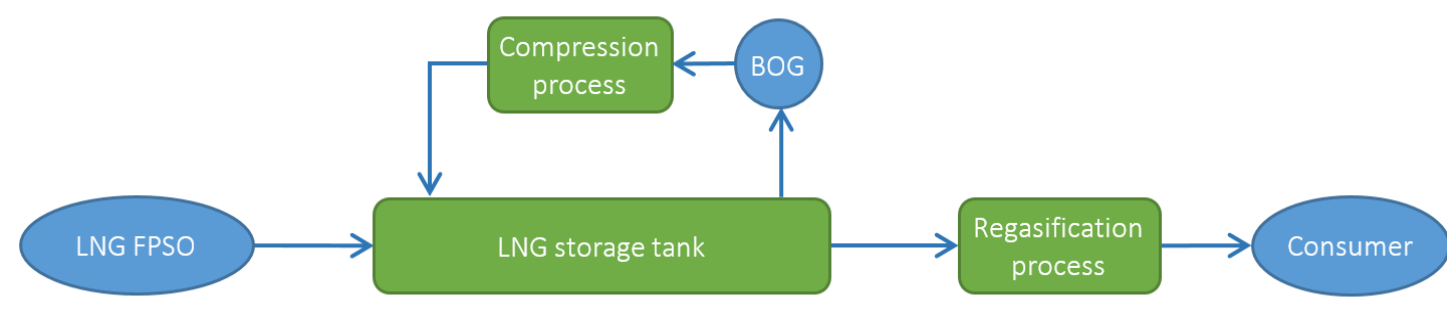

Figure 5. The simplified process flow of a LNG Harbor Depot [5] 


\section{CONCLUSIONS}

The energy demand is growing rapidly in Vietnam, while domestic natural gas resource is decreasing. Therefore, the LNG importation will be growing up to compensate the degradation. The total LNG requirement is forecasted of 13.75 and 112.43 million tons in the 2019-2025 and the 2026-2035 phases, respectively. In detailed, the LNG importation will have to start up in 2019 for The Southeast region, in 2022 for The Southwest region, in 2025 for The North region and accelerate the capacity since 2027 . Especially for The Central region, the natural gas supply is higher than demand, the small scale LNG production plant should be hence considered. As a result, the Vietnamese LNG market will grow potentially. Furthermore, the application of optimizing technology to Vietnamese LNG production is indispensable and has to be researched as soon as possible.

\section{Toàn cảnh ngành công nghiệp chế biến khí ở Việt Nam và vai trò của khí hóa lỏng (LNG) trong giai đoạn 2011-2035}

- Đặng Đình Thắng

- Huỳnh Quyền

- Tạ Đăng Khoa

Trường Đại học Bách Khoa, ĐHQG-HCM

\section{TÓM TẮT}

Bài báo trình bày số liệu chi tiết về nhu cầu khí cho ngành công nghiệp điện, phân bón và các ngành khác trong giai đoạn 2011-2015, kèm theo số liệu dụ báo trong các giai đoạn 2016-2025 và 2026-2035. Số liệu thống kê cho

thấy ngành công nghiệp chế biến khí nội địa không thể đáp úng được nhu cầu của thị truòng, luợng thiếu hut lên đến 30\%. Một giải pháp khả thi cho vấn đề này là xây dựng các kho bãi có khả năng xuất nhập và tồn trũ khí thiên nhiên 
hóa lỏng (LNG). Tuy nhiên, hạn chế chính là mang luơoi đường ống dẫn khí trong cả nuớc không thông suốt, bị chia nhỏ thành nhiều khu vưc rời rạc. Vì thế công nghệ xuất nhập và tồn trũ của các kho bãi $L N G$ phải đuợc chọn lựa và thiết kế một cách hợp lý. Phân tích số liệu cho thấy thị trường LNG tại Việt Nam có tiềm năng phát triển cao trong giai đoạn 2016-2035.

Tù khóa: Khí thiên nhiên hóa lỏng ( $L N G)$, công nghiệp chế biến khí, thị truờng khí thiên nhiên hóa lỏng $(L N G)$

\section{REFERENCES}

[1]. PetroVietnam (PVN), "PV Gas's development strategy to 2025 and orientation to 2035” Hanoi, Vietnam, 2015.

[2]. OG Analysis, "Vietnam oil gas trends, market opportunities and outlook to 2025", Report OG Analysis 2224, Dreieich, Germany, July 2014.

[3]. International Energy Agency (IEA), "Energy and Climate Change", World Energy Outlook Special Report (OECD/IEA, 2015), Paris, France, 2015.

[4]. The U.S. Energy Information Administration (EIA), "International Energy Outlook 2014", Report DOE/EIA0484(2014), Washington, U.S.A., September 2014.

[5]. G.K. Frank, "Industrial gas handbook: Gas separation and purification", CRC Press, 2007.
[6]. E. Querol, B. Gonzalez-Regueral, J. Garcia-Torrent, M.J. Garcia-Martinez, "Boil off gas (BOG) management in Spanish liquid natural gas (LNG) terminals", Applied Energy 87 (2010); 3384-3392.

[7]. Y. Demirel, "Energy - Production, conversion, storage, conservation and coupling”, Springer-Verlag London, 2012.

[8]. Shengchun Liu, Xueqiang Li, Yan Huo, Hailin $\mathrm{Li}$, "An analysis of the primary energy consumed by the re-liquefaction of boil-off gas of LNG storage tank", Energy Procedia 75 (2015); 3315-3321.

[9]. J. Romero Gómez, M. Romero Gómez, J. Lopez Bernal, A. Baalina Insua, "Analysis and efficiency enhancement of a boil-off gas re-liquefaction system with cascade cycle on board LNG carriers", Energy Conversion and Management 94 (2015); 261-274. 